\title{
FORECASTING THE BASIC CONDITIONS OF INDONESIA'S RICE ECONOMY 2019-2045
}

\author{
Zainul Arifin ${ }^{1 *}$, Nuhfil Hanani ${ }^{2}$, Djoko Kustiono ${ }^{2}$, Syafrial $^{2}$, Rosihan Asmara ${ }^{2}$ \\ ${ }^{1}$ Deparment of Agribusiness, Faculty of Agriculture, University of Islam Malang, Indonesia \\ ${ }^{2}$ Deparment of Socio Economic, Faculty of Agriculture, Brawijaya University, Indonesia \\ *corresponding author: zainul@unisma.ac.id
}

\begin{abstract}
By 2045, Indonesia's population is expected to reach 321.4 million, the fifth largest in the world after China, India, Nigeria, and the United States. It is an excellent challenge for Indonesia to provide food in the future as it keeps pace with the rapid population growth. This study aims to analyze forecasting the basic conditions of Indonesia's rice economy 2019-2045. The research data use time-series data from 1961-2018, including data from the Central Bureau of Statistics (BPS), Ministry of Agriculture/Pusdatin, Food and Agriculture Organization (FAO), International Rice Research (IRR), Department of Commerce, United States Department of Agriculture (USDA), and ASEAN Food Safety Information System (AFSIS). Data analysis using the simultaneous equations model approach. The results show that in 2019-2045 the projection of rice productivity in 2025 is 64,465 quintals per hectare; in 2035, it is 68,797 quintals per hectare, and in 2045 it is 77,462 quintals per hectare. In 2045, the projected land area is 27.64 million hectares. Although Indonesia is forecast to experience a rice surplus of 37.80 million tonnes in 2045 , the projected rice production and domestic rice consumption level indicate the potential for rice imports of 15 million tonnes.
\end{abstract}

Keywords: rice economic model, policy, forecasting, gold Indonesia 2045

http://dx.doi.org/10.21776/ub.agrise.2021.021.2.4

Received 6 November 2020

Accepted 29 April 2021

Available online 30 April 2021

\section{INTRODUCTION}

Indonesia establishes a strategy to achieve the production of food crops through four strategies or what is known as the four Strategies to achieve the production of food crops including: 1) Increase productivity 2) Expansion of the area and land optimization 3) Reduce rice consumption and develop food diversification and 4) Improve management (Agbachom et al., 2019; Pichler, 2015; Sulaiman et al., 2019; Utami et al., 2020). Increasing rice productivity is carried out by accompanying, mentoring, advising, and coordinating the following activities: 1) Assemble, disseminate and implement appropriate technology packages specifically for technology application and development, 2) GP3K (Movement to increase business-based food production), 3) Protection of food plants against pests and IPR disturbances, and 4) A decrease in yield loss and increase in rice yield.

The development of food crops by expanding the planting area is carried out by 1 ) printing new land (rice fields); 2) land optimization by increasing the crop index (PI); 3) optimization of another agricultural land; and 4) optimization of abandoned land (Choi et al., 2019; Junaidi et al.,
2020; Neilson et al., 2020; Wicke et al., 2011). The efforts made by the government do not seem to have achieved optimal results, where the achievement of rice production is relatively insignificant compared to the rate of population increase, and there is a tendency for rice production to have a declining pattern in recent years (Fadhliani et al., 2019; Graham et al., 2020; Maraseni et al., 2018).

Rice is a strategic commodity besides soybeans, maize, beef, shallots, and sugar (Sa'diyah et al., 2019). Rice is also the staple food source of carbohydrate food in Indonesia. The share of household expenditure on rice is the largest across all household income quintiles (Nikmatul et al., 2020). The food problem in Indonesia is problematic concerning the increasing population (Hidayaturrahman \& Husamah, 2020; Rusliyadi et al., 2020.; Setiadi et al., 2020). By 2045, Indonesia's population is expected to reach 321.4 million, the fifth largest in the world after China, India, Nigeria, and the US. It is a big challenge for Indonesia to provide food because it keeps pace with the rapidly increasing population growth rate. Today's decisions will determine whether Indonesia can meet the food needs of a future with a population that continues to 
increase. The vision for the future in rice policy is to make Indonesia a world food barn by 2045 (Arifin et al., 2018). The scenario for a world food barn is through several stages. Each stage requires serious political will and action, including infrastructure support and technological innovation, strengthening agricultural institutional from all lines, both at the central and regional levels. The scenario towards a world food barn is through several stages. Each stage requires a serious political will and political action (Meuwissen et al., 2019; Mora et al., 2020; Movilla-Pateiro et al., 2020).

Research on the rice policy scenario has been carried out in several countries ie (Abdulai \& Huffman, 2000; Acee-Eke, 2018.; Biondi et al., 2019; Graham et al., 2020; Maraseni et al., 2018; Moayedfar et al., 2020). Research on forecasting the basic conditions of the Indonesian Rice Economy in 2045 is still rare. Therefore, this study aims to analyze forecasting the basic conditions of Indonesia's rice economy 2019-2045. The research data uses secondary data in the form of time-series data from 1961-2018, derived from national and international data. Data analysis uses the Simultaneous Equation Model approach to project 12 rice economic models in 2019-2045. The research results are expected to be valuable input for the government to achieve food security, especially rice self-sufficiency towards a golden Indonesia in 2045.

\section{METHODS}

This research is a follow-up study from the initial research on the Indonesian rice economic model's overview. At the initial stage of the research, 12 models were tested to analyze the Indonesian rice economic model. The Indonesian rice economic model consists of 12 models (Table 1). The simultaneous analysis was carried out to obtain the parameters of all models (Santilano et al., 2018; Sarwar et al., 2017). Of the 12 models, 11 models are significant and only 1 model, namely rice imports, is not significant. In this study, the 12 models were simulated using the ex-ante method for the years 2019-2045.

Table 1. Indonesia's Rice Economic Models

\begin{tabular}{|c|c|c|c|}
\hline No & Model & Formulation & Variables \\
\hline 1 & Rice area & $\begin{array}{l}\mathrm{APt}=\mathrm{ao}+\mathrm{a} 1 \mathrm{ASt}+\mathrm{a} 2 \mathrm{PPt}+ \\
\mu 1\end{array}$ & $\begin{array}{l}\mathrm{APt}=\text { paddy area (hectar) } \\
\mathrm{ASt}=\text { wet land area }(\text { hectar }) \\
\mathrm{PPt}=\text { paddy price }(\mathrm{Rp} / \mathrm{kg}) \\
\text { Prediction mark of the expected parameters } \\
\mathrm{a} 1>0, \mathrm{a} 2>0 \text {, and a }<0\end{array}$ \\
\hline 2 & $\begin{array}{l}\text { Rice } \\
\text { production }\end{array}$ & $\mathrm{QBt}=\mathrm{a} 2 * \mathrm{SPt}$ & $\begin{array}{l}\mathrm{a} 2 \mathrm{t}=\text { rice rendemen (percent) } \\
\mathrm{SPt}=\text { paddy suplpy (ton) }\end{array}$ \\
\hline 3 & $\begin{array}{l}\text { Rice } \\
\text { productivity }\end{array}$ & $\begin{array}{l}\mathrm{YPt}=\mathrm{bo}+\mathrm{b} 1 \mathrm{Lt}+\mathrm{b} 2 \mathrm{FNt}+ \\
\mathrm{b} 3 \mathrm{FPt}+\mathrm{b} 4 \mathrm{FKt}+\mathrm{b} 5 \mathrm{PESTt}+ \\
\mathrm{b} 6 \mathrm{TEKt}+\mu 2\end{array}$ & $\begin{array}{l}\text { YPt Paddy productivity (kwintal/hectar) } \\
\mathrm{Lt}=\text { labour usage (person) } \\
\mathrm{FNt}=\mathrm{N} \text { Fertilizer usage (ton) } \\
\mathrm{FPt}=\mathrm{P} \text { fertilizer usage (ton) } \\
\mathrm{FKt}=\mathrm{K} \text { fertilizer usage (ton) } \\
\text { Pestt }=\text { Pesticide usage (ton) } \\
\text { Tekt }=\text { Level of technology application } \\
\text { (Productivuty index) } \\
\text { Prediction mark of the expected parameters } \\
\mathrm{b} 1>0, \mathrm{~b} 2>0, \mathrm{~b} 3>0, \mathrm{~b} 4>0, \mathrm{~b} 5>0, \text { and } \mathrm{b} 6>0\end{array}$ \\
\hline 4 & $\begin{array}{l}\text { Demand for } \\
\text { Labour }\end{array}$ & $\begin{array}{l}\mathrm{Lt}=\mathrm{c} 0+\mathrm{c} 1 \mathrm{PPt}+\mathrm{c} 2 \text { it }+\mathrm{c} 3 \\
\mathrm{KREt}+\mathrm{c} 4 \text { POPRt }+\mu 3\end{array}$ & $\begin{array}{l}\mathrm{Lt} \quad=\text { Labour usage }(\text { person }) \\
\mathrm{PPt} \quad=\text { paddy price }(\mathrm{Rp} / \mathrm{kg}) \\
\text { it } \quad=\text { rate of interest (percent) } \\
\mathrm{KREt}=\text { Total credit (rupiah) } \\
\mathrm{POPRt}=\text { agricultural sector labor wages }(\mathrm{Rp} / \mathrm{HOK}) \\
\text { Prediction mark of the expected parameters } \\
\mathrm{c} 1>0, \mathrm{c} 2<0, \mathrm{c} 3>0, \text { and } \mathrm{c} 4>0\end{array}$ \\
\hline 5 & $\begin{array}{l}\text { Nitrogen } \\
\text { fertilizer } \\
\text { Usage }\end{array}$ & $\begin{array}{l}\text { FNt }=d 0+d 1 P f n t+d 2 P P t+ \\
d 3 A P t+d 4 \text { It }+ \text { d5 KREt }+ \\
\mu 4\end{array}$ & $\begin{array}{l}\mathrm{FNt}=\mathrm{N} \text { Fertilizer usage }(\text { ton }) \\
\mathrm{Pfnt}=\mathrm{N} \text { Fertilizer price }(\mathrm{Rp} / \mathrm{kg}) \\
\mathrm{PPt}=\mathrm{Paddy} \text { price }(\mathrm{Rp} / \mathrm{kg}) \\
\mathrm{APt} \quad=\text { paddy area (hectar) } \\
\text { It } \quad=\text { rate of interest (percent) } \\
\mathrm{KREt}=\text { the amount of credit extended }(\mathrm{Rp}) \\
\text { Prediction mark of the expected parameters } \\
\mathrm{d} 1<0, \mathrm{~d} 2>0, \mathrm{~d} 3>0, \mathrm{c} 4<0, \text { and } \mathrm{d} 5>0\end{array}$ \\
\hline 6 & $\begin{array}{l}\text { Phosphat } \\
\text { fertilizer usage }\end{array}$ & $\begin{array}{l}F P t=d 0+d 1 P f p t+d 2 P P t+ \\
d 3 A P t+d 4 I t+d 5 K R E t+\mu 5\end{array}$ & $\begin{aligned} \mathrm{FPt} & =\mathrm{P} \text { fertilizer usage }(\mathrm{ton}) \\
\mathrm{Pfpt} & =\mathrm{P} \text { fretilizer price }(\mathrm{Rp} / \mathrm{kg})\end{aligned}$ \\
\hline
\end{tabular}




\begin{tabular}{|c|c|c|c|}
\hline No & Model & Formulation & Variables \\
\hline & & & $\begin{array}{l}\mathrm{PPt}=\text { Paddy price }(\mathrm{Rp} / \mathrm{kg}) \\
\mathrm{APt}=\text { Paddy area (hectar) } \\
\mathrm{It} \quad=\text { rate of interest (percent) } \\
\mathrm{KREt}=\text { the amount of credit extended }(\mathrm{Rp}) \\
\text { Prediction mark of the expected parameters } \\
\mathrm{d} 1<0, \mathrm{~d} 2>0, \mathrm{~d} 3>0, \mathrm{c} 4<0, \text { and } \mathrm{d} 5>0\end{array}$ \\
\hline 7 & $\begin{array}{l}\text { Kalium } \\
\text { fertilizer usage }\end{array}$ & $\begin{array}{l}\mathrm{FKt}=\mathrm{e} 0+\mathrm{e} 1 \mathrm{Pfkt}+\mathrm{e} 2 \mathrm{PPt}+ \\
\mathrm{e} 3 \mathrm{APt}+\mathrm{e} 4 \mathrm{It}+\mathrm{e} 5 \mathrm{KREt}+\mu 6\end{array}$ & $\begin{array}{l}\text { FKt }=\mathrm{K} \text { Fertilizer usage (ton) } \\
\mathrm{Pfkt}=\mathrm{K} \text { fertilizer price }(\mathrm{Rp} / \mathrm{kg}) \\
\mathrm{PPt}=\text { Paddy price }(\mathrm{Rp} / \mathrm{kg}) \\
\mathrm{APt}=\text { luas areal padi (hectar) } \\
\mathrm{It} \quad=\text { rate of interest (percent) } \\
\text { KREt }=\text { the amount of credit extended (Rp) } \\
\text { Prediction mark of the expected parameters } \\
\mathrm{e} 1<0, \mathrm{e} 2>0, \mathrm{e} 3>0, \mathrm{e} 4<0, \text { and e } 5>0\end{array}$ \\
\hline 8 & Pesticide usage & $\begin{array}{l}\text { FPESTt }=\mathrm{g} 0+\mathrm{g} 1 \text { Ppestt }+ \\
\mathrm{g} 2 \mathrm{PPt}+\mathrm{g} 3 \mathrm{APt}+\mathrm{g} 4 \mathrm{it}+\mathrm{d} 5 \\
\text { KREt }+\mu 7\end{array}$ & $\begin{array}{l}\text { FKt }=\text { Pesticide usage (ton) } \\
\text { Ppestt }=\text { Pesticide price }(\mathrm{Rp} / \mathrm{kg}) \\
\mathrm{PPt} \quad=\text { Paddy price }(\mathrm{Rp} / \mathrm{kg}) \\
\mathrm{APt} \quad=\text { Paddy area (hectar) } \\
\mathrm{It} \quad=\text { interest rate (percent) } \\
\mathrm{KREt}=\text { the amount of credit extended }(\mathrm{Rp}) \\
\text { Prediction mark of the expected parameters } \\
\mathrm{g} 1<0, \mathrm{~g} 2>0, \mathrm{~g} 3>0, \mathrm{~g} 4<0, \text { and } \mathrm{g} 5>0\end{array}$ \\
\hline 9 & $\begin{array}{l}\text { Individual } \\
\text { Rice demand }\end{array}$ & $\begin{array}{l}\mathrm{DB} 0 \mathrm{t}=\mathrm{mo}+\mathrm{m} 1 \mathrm{PBt}+ \\
\mathrm{m} 2 \mathrm{INCt}+\mathrm{m} 3 \mathrm{PPHt}+\mu 9\end{array}$ & $\begin{array}{l}\text { DB0t }=\text { individual rice demand year- } \mathrm{t} \\
(\mathrm{kg} / \mathrm{capita} / \text { year }) \\
\mathrm{PBt}=\text { rice price year-t }(\mathrm{Rp} / \mathrm{kg}) \\
\mathrm{INCt}=\text { income per capita year-t }(\mathrm{Rp} / \text { capita/year) } \\
\mathrm{PPHt}=\text { desirable food pattern (Pola Pangan } \\
\text { Harapan/PPH) year-t (percent) } \\
\text { Prediction mark of the expected parameters } \\
\mathrm{m} 1<0, \mathrm{~m} 2>0, \mathrm{~m} 3<0 \\
\text { Prediction mark of the expected parameters } \\
\mathrm{p} 1>0, \mathrm{n} 2<0, \text { and } \mathrm{n} 3>0\end{array}$ \\
\hline 10. & $\begin{array}{l}\text { Domestic rice } \\
\text { price }\end{array}$ & $\begin{array}{l}\mathrm{PBt}=\mathrm{n} 0+\mathrm{n} 1 \mathrm{DBt}+\mathrm{n} 2 \mathrm{SBt}+ \\
\mathrm{n} 3 \text { Excht }+\mu 10\end{array}$ & $\begin{array}{l}\mathrm{PBt}=\text { domestic rice price year-t }(\mathrm{Rp} / \mathrm{kg}) \\
\mathrm{DBt}=\text { domestic rice demand year-t (ton) } \\
\mathrm{SBt}=\text { rice supply year-t (ton) } \\
\text { Excht = exchange rate year-t (Rp/US } \$ \text { ) } \\
\text { Prediction mark of the expected parameters } \\
\mathrm{n} 1>0, \mathrm{n} 2<0, \text { and } \mathrm{n} 3>0\end{array}$ \\
\hline 11 & Paddy price & $\begin{array}{l}\mathrm{PPt}=\mathrm{p} 0+\mathrm{p} 1 \mathrm{PBt}+\mathrm{p} 2 \mathrm{QPt}+ \\
\mathrm{p} 3 \mathrm{HPPt}+\mu 10\end{array}$ & $\begin{array}{l}\mathrm{PPt}=\text { paddy price } \\
\text { p0 = contant } \\
\text { p1PBt }=\text { rice demand in year- } \mathrm{t} \\
\mathrm{P} 2 \mathrm{QPt}=\text { rpaddy production in year } \mathrm{t} \\
\mu 10=\text { Prediction mark of the expected parameters }\end{array}$ \\
\hline 12 & Rice import & $\begin{array}{l}\mathrm{MBt}=\mathrm{h} 0+\mathrm{h} 1 \mathrm{PBt}+\mathrm{h} 2 \mathrm{PWBt} \\
+\mathrm{h} 3 \mathrm{QBt}+\mathrm{h} 4 \mathrm{DBt}+\mu 8\end{array}$ & $\begin{array}{l}\mathrm{MBt}=\text { The amount of rice imported in year } \mathrm{t}(\mathrm{ton}) \\
\mathrm{PBt}=\text { Domestic price rice year-t }(\mathrm{Rp} / \mathrm{kg}) \\
\mathrm{PWBt}=\text { world rice price year-t }(\mathrm{US} \$ / \mathrm{ton}) \\
\mathrm{QBt}=\text { rice production year-t (ton) } \\
\mathrm{DBt}=\text { rice total demand year-t }(\text { ton) } \\
\text { Prediction mark of the expected parameters } \\
\mathrm{h} 1>0, \mathrm{~h} 2<0, \mathrm{~h} 3<0, \mathrm{~h} 4>0 \text { dan } 0<\mathrm{h} 5<1\end{array}$ \\
\hline
\end{tabular}

Source: Author's modelling

Data

The data used in this research is time-series data and collected by the documentary methoddata obtained by taking secondary data from various data that have been published by national and international institutions. The data based on time series from 1961 - 2018. The data collected are from
1. Central Bureau of Statistics (BPS) 2. Ministry of Agriculture/ Pusdatin, 3. Food Agriculture Organization (FAO) ) 4. International Rice Research (IRR) 5. Ministry of Trade 6. United States Department of Agriculture (USDA), and 7. ASEAN Food Security Information System (AFSIS). 


\section{RESULTS AND DISCUSSIONS \\ 1. Model validation}

The results of the analysis of the Indonesian rice economic model using the Root
Mean Square Error (RMSE) and Root Means Square Percent Error (RMSPE) indicators are represented by the deviation value, which is the difference between the actual average value (actual mean) and the predicted average (predicted mean). The result is presented in Table 2.

Tabel 2: Validation Results with Deviation Value Indicators

\begin{tabular}{lllll}
\hline No. & Variabel & Actual Mean & $\begin{array}{l}\text { Predicted } \\
\text { Mean }\end{array}$ & $\begin{array}{l}\text { Deviasi } \\
(\%)\end{array}$ \\
\hline 1. & Paddy Area (AP) & 21576933 & 24475426 & 0.13 \\
2 & Paddy Supplay (SP) & 82344056 & 97450000 & 0.18 \\
3. & Paddy productivity (YP) & 65.3492 & 51.6875 & -0.21 \\
4. & Paddy production (QP) & 118600000 & 148000000 & 0.25 \\
5 & Rice production (QB) & 65307613 & 54499243 & -0.17 \\
6. & Kehilangan Padi (KP) & 4758058 & 6863398 & 0.44 \\
7. & Rice Supply (SB) & 36237064 & 74695071 & 1.06 \\
8. & Labor Usage (L) & 32442.1 & 47322 & 0.46 \\
9. & N fertilizer usage (FN) & 4664088 & 7469556 & 0.60 \\
10. & P Fertilizer usage (FP) & 901705 & 1130058 & 0.25 \\
11. & K fertilizer usage (FK) & 5071368 & 4129320 & -0.19 \\
12. & Pesticide usage (FPest) & 3597 & 4047 & 0.13 \\
13. & Rice demand (DB) & 38220992 & 41190000 & 0.08 \\
14. & Rice demand per capita (DBO) & 129.8 & 229.7 & 0.77 \\
15. & Rice import (MB) & 8223625 & 1793291 & -0.78 \\
16. & Rice price (PB) & 12057.3 & 14755.5 & 0.22 \\
17. & Paddy price (PP) & 667.4 & 1049.2 & 0.57 \\
& Rates & & & 0.22 \\
\hline
\end{tabular}

Sumber: Authors computation

The predicted average value that is closer to the actual average value shows better validity. Table 2 shows that the lowest deviation value (regardless of the sign) is $0.13 \%$, and the highest deviation value is $78 \%$, while the average deviation is $22 \%$. The value of this deviation occurs considering that the period used for forecasting is 27 years; taking into account the length of the time, the rice economic model built is quite valid because the predictions made can approach the actual value.

Table 3 shows the results of validation analysis using statistical indicators for the U-Theil value (Theil Inequality Coefficient) and their decomposition, namely proportion bias (MW), variance bias (US), and covariance bias (UC) of the Indonesian rice economic model. The statistical indicators are used to evaluate a model's ability to analyze simulations, historical simulations, and exante simulations. The principle is that the smaller it is, the better the estimation of the model. Good UM and US values are close to 0 , while a good UC value is close to 1 .

Table 3 also shows that the lowest U-Theil value is 0.0720 , and the highest U-Theil value is 0.8542 , while the average U-Theil value is 0.34 . The lowest MW was 0.61, and the highest MW was 0.99 , while the average MW was 0.83 . The lowest US value was 0.0000 , and the highest US value was 0.33 , while the US average was 0.016 . The lowest UC was 0.0000 , and the highest UC was 0.15 , while the average UC was 0.02 . Because the average UTheil value is relatively small, and the US value is close to one, the model is quite valid and can be used in the simulatory analysis.

Table 3. Validation test with Indicator U-Theil, $\mathrm{U}^{\mathrm{M}}, \mathrm{U}^{\mathrm{S}}$, dan $\mathrm{U}^{\mathrm{C}}$

\begin{tabular}{llllll}
\hline No. & Variable & $\mathrm{U}-T h e i l$ & $\mathrm{U}^{\mathrm{M}}$ & $\mathrm{U}^{\mathrm{S}}$ & $\mathrm{U}^{\mathrm{C}}$ \\
\hline 1. & Paddy Area (AP) & 0.0720 & 0.74 & 0.26 & 0.00 \\
2. & Paddy Supplay (SP) & 0.8981 & 0.93 & 0.07 & 0.00 \\
3. & Paddy productivity (YP) & 0.1304 & 0.80 & 0.18 & 0.02 \\
4. & Paddy production (QP) & 0.8542 & 0.94 & 0.06 & 0.00 \\
5. & Rice production (QB) & 0.3254 & 0.84 & 0.07 & 0.09 \\
6 & Kehilangan Padi (KP) & 0.0974 & 0.85 & 0.15 & 0.00 \\
7. & Rice Supply (SB) & 0.3589 & 0.92 & 0.08 & 0.00 \\
8. & Labor Usage (L) & 0.2022 & 0.85 & 0.00 & 0.15 \\
9. & N fertilizer usage (FN) & 0.2554 & 0.78 & 0.22 & 0.00 \\
10. & P Fertilizer usage (FP) & 0.4341 & 0.79 & 0.21 & 0.00 \\
\hline
\end{tabular}




\begin{tabular}{llllll}
\hline No. & Variable & U-Theil & $\mathrm{U}^{\mathrm{M}}$ & $\mathrm{U}^{\mathrm{S}}$ & $\mathrm{U}^{\mathrm{C}}$ \\
\hline 11. & K fertilizer usage (FK) & 0.1083 & 0.82 & 0.18 & 0.00 \\
12. & Pesticide usage (FPest) & 0.5775 & 0.86 & 0.14 & 0.00 \\
13. & Rice demand (DB) & 0.0720 & 0.99 & 0.22 & 0.00 \\
14. & Rice demand per capita (DBO) & 0.2995 & 0.84 & 0.14 & 0.01 \\
15. & Rice import (MB) & 0.6710 & 0.78 & 0.22 & 0.00 \\
16. & Rice price (PB) & 0.1213 & 0.67 & 0.33 & 0.00 \\
17. & Paddy price (PP) & 0.2605 & 0.71 & 0.22 & 0.07 \\
& Rata-rata & 0.34 & 0.83 & 0.16 & 0.02 \\
\hline
\end{tabular}

Source: Authors computation

\section{Forecasting the Basic Conditions of Indonesia's Rice Economy}

The results of the forecast analysis for the basic economic conditions of Indonesian rice for the 2019-2045 period are shown in Table 4. Table 4 shows that rice's world price is $\$ 401.72 /$ ton, and the domestic price of Indonesian rice is 683.53/ton. The world price of rice, which is cheaper than the domestic price of rice, will encourage market players to import rice from abroad by taking advantage of this sizeable price difference and can disrupt the market balance between rice producers (farmers) and consumers

Due to Indonesia's rice harvest area of $16,384,243.89$ hectares and Indonesian rice productivity of 54.9335/hectare, Indonesia's paddy production is $86,090,811.88$ tons, and if it is turned into rice, it will produce rice of 53,391,029.56 tons. Meanwhile, the amount of demand for rice in this base year is $35,030,336.13$ tons. It illustrates that domestic rice production can meet $100 \%$ of all Indonesian rice demand, and it is even open for Indonesia to become a rice exporter considering that there is a rice surplus of 18,360,693.4 tons.

The increase in population will cause an increase in food consumption. In 2015, Indonesia's total population was 257 million, with a population increase rate of 1.29 percent compared to the previous year. Suppose the increase in population growth rate cannot be suppressed. In that case, it will lead to a relatively large increase in rice needs' fulfillment regarding the community's considerable dependence on large amounts of food as a source of food and a burden for efforts to increase economic growth rates.

Table 4. Forecasting the Basic Conditions of Indonesia's Rice Economy

\begin{tabular}{clr}
\hline No & \multicolumn{1}{c}{ Variable } & \multicolumn{1}{c}{ Based value } \\
\hline 1 & Paddy Area (AP) & $16,384,243.89$ \\
2 & Paddy Supplay (SP) & $74,540,265.14$ \\
3 & Paddy productivity (YP) & $54,933.50$ \\
4 & Paddy production (QP) & $86,090,811.88$ \\
5 & Rice production (QB) & $5,213,693.09$ \\
6 & Kehilangan Padi (KP) & $53,391,029.56$ \\
7 & Rice Supply (SB) & $36,239,784.57$ \\
8 & Labor Usage (L) & $3,177,950.00$ \\
9 & N fertilizer usage (FN) & $3,910,254.88$ \\
10 & P Fertilizer usage (FP) & $684,340.41$ \\
11 & K fertilizer usage (FK) & $2,537,654.06$ \\
12 & Pesticide usage (FPest) & $1,597.00$ \\
13 & Rice demand (DB) & $35,030,336.13$ \\
14 & Rice demand per capita & $131,026.00$ \\
& (DBO) & \\
15 & Rice import (MB) & $2,408,266.04$ \\
16 & Rice price (PB) & 401.72 \\
17 & Paddy price (PP) & $10,082.00$ \\
18 & Domestic Price Rice (PB) & 683,53 \\
& (US\$/ton) & $6,915.04$ \\
\hline 19 & Paddy Price (PP) (Rp/kg)
\end{tabular}

Source: Authors computation 


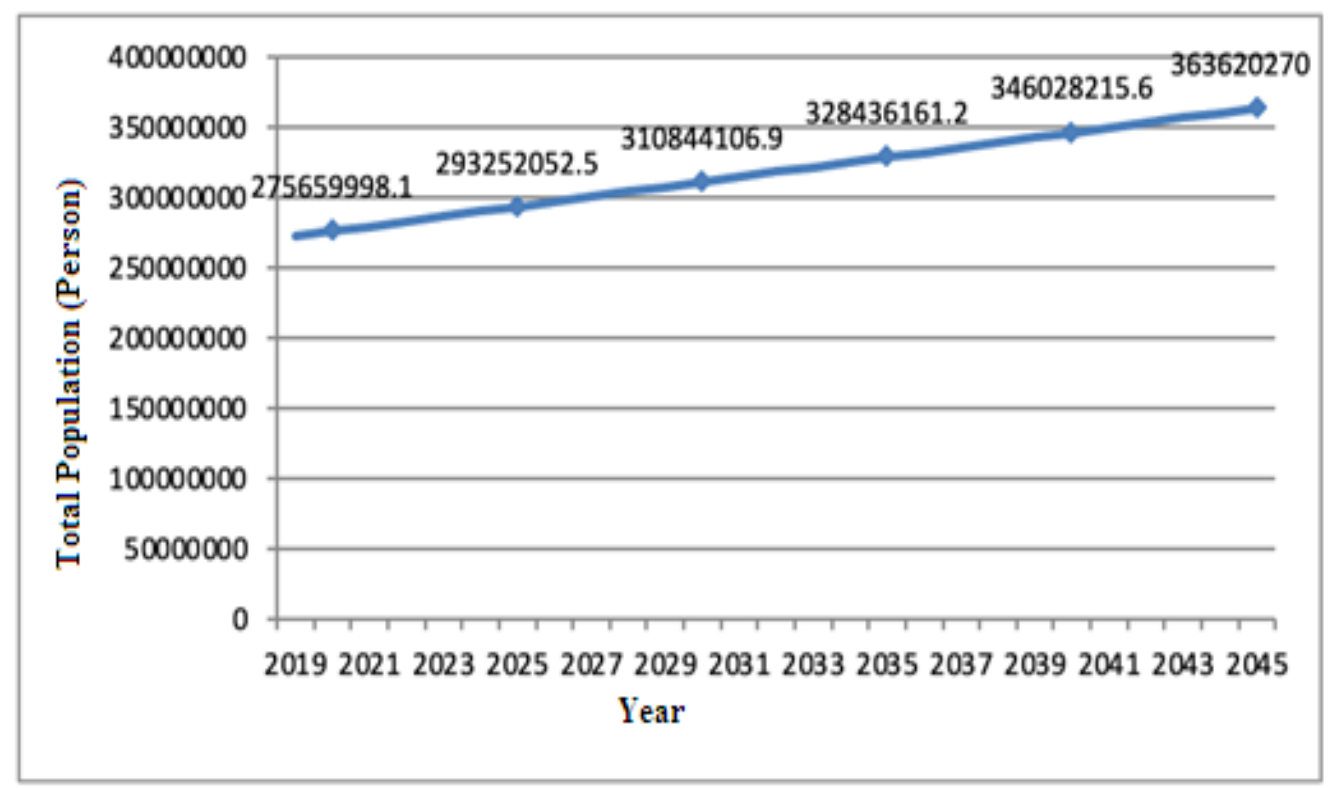

Figure 1. Forecasting of Indonesia's Population in 2020 - 2045

The movement to suppress the population growth rate is expected to suppress the population growth rate at the level of 1.11 percent. Then the population in 2020 is projected to be 275 million people. This study indicates that the population growth rate in 2025 is 1.21 percent, in 2035 is 1.08 percent, and in 2045 is 0.98 percent. The average decline in the population growth rate of still 1.12 percent (Figure 2), with an average population growth rate of 1.12 percent in 2025 , the total population of Indonesia is 293 million, in 2035 it will be 328 people, and in 2045, the projected population of Indonesia is 364 million. According to the data, the population of Indonesia in 2025 in 2925,2 million people, in 2035 in 328.4 million people and in 2045 in 363.4 million people (Figure 1).

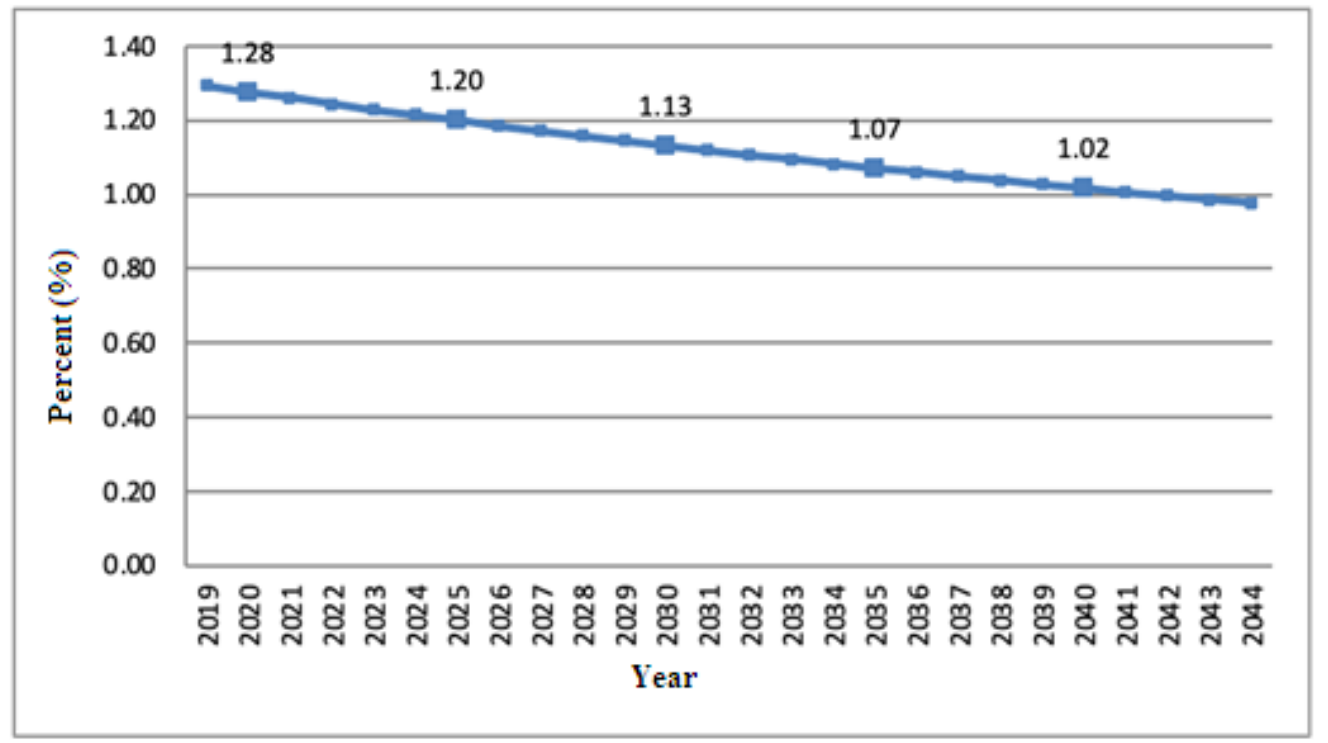

Figure 2. Projection of Indonesia's Population Growth Rate 2020 - 2045

Table 5 shows a slowdown in the population growth rate, although it is not too large. The demand for rice is calculated using the calculation of rice consumption, both direct rice consumption and indirect consumption per capita per year multiplied by the total population. Direct rice consumption is household consumption of the use of rice or rice-based foodstuffs. The figure for rice consumption per capita per year, for example, in 2012 was $132.98 \mathrm{~kg}$ (BPS and Ministry of Agriculture 2012). This figure is obtained from the sum of the rice consumption rate at the household level (Susenas result) of $97.65 \mathrm{~kg}$ per capita per year and rice outside the household of $35.33 \mathrm{~kg}$ per capita per year. 
Table 5. Projected Population and Population Growth Rate of Indonesia 2019 - 2045

\begin{tabular}{cccc}
\hline No & Year & $\begin{array}{c}\text { Number of } \\
\text { population } \\
\text { (Person) }\end{array}$ & $\begin{array}{c}\text { Growth } \\
(\%)\end{array}$ \\
\hline 1 & 2019 & 272.141 .587 & \\
2 & 2021 & 279.178 .409 & 1.28 \\
3 & 2023 & 286.215 .230 & 1.24 \\
4 & 2025 & 293.252 .052 & 1.21 \\
5 & 2027 & 300.288 .874 & 1.19 \\
6 & 2029 & 307.325 .696 & 1.16 \\
7 & 2031 & 314.362 .517 & 1.13 \\
8 & 2033 & 321.399 .339 & 1.11 \\
9 & 2035 & 328.436 .161 & 1.08 \\
10 & 2037 & 335.472 .983 & 1.06 \\
11 & 2039 & 342.509 .804 & 1.04 \\
12 & 2043 & 356.583 .448 & 1.00 \\
13 & 2045 & 363.620 .270 & 0.98 \\
Rata-rata & 317.880 .928 & 1.12 \\
\hline
\end{tabular}

Source: Authors computation
The result of this study reflects decreasing rice consumption per capita per year. In 2019 rice consumption in Indonesia was 131. $23 \mathrm{~kg}$ per capita per year; In 2025, it is $130.39 \mathrm{~kg}$ per capita per year; in 2035 , it is $129.33 \mathrm{~kg}$ per capita per year. It is estimated that in 2045, rice consumption will be 128.277 kg per capita per year. Although there has been a decline in rice consumption per capita per year, the population growth rate is higher than the growth rate of decline in rice consumption per capita per year, causing total consumption of rice is still increasing. Table 6 and Figure 3 shows that in 2015, rice consumption was 31.9 million tons. The amount of consumption was obtained by multiplying the assumed consumption figure of $124.89 \mathrm{~kg}$ capita per year, with 255.46 million people. In the same way, in 2020 , it is projected that the need for rice consumption is 33.60 million tons, and in 2025 it will be 35.34 million tons. In 2030, it will be 36.70 million tons, and in 2035 it will be 37.8 million tons. In 2040, it will be 38.94 million tons, and in 2045 it will be 39.80 million tons (BPS, 2015).

Table 6. Projections of Total Population, Consumption Per Capita / year, and Rice Demand by Year 2019 - 2045

\begin{tabular}{cccccccc}
\hline No & Year & $\begin{array}{c}\text { Total } \\
\text { Population } \\
\text { (person) }\end{array}$ & $\begin{array}{c}\text { Growth } \\
(\%)\end{array}$ & $\begin{array}{c}\text { Consumption } \\
\text { rice } \\
\text { (Capita/year) }\end{array}$ & $\begin{array}{c}\text { Growth } \\
(\%)\end{array}$ & $\begin{array}{c}\text { Demand rice } \\
(\%)\end{array}$ & $\begin{array}{c}\text { Growth } \\
(\%)\end{array}$ \\
\hline 1 & 2019 & 272141587 & & 131.03 & & 35030336 & \\
2 & 2021 & 279178409 & 1.28 & 130.18 & -0.57 & 35521206 & 0.70 \\
3 & 2023 & 286215231 & 1.24 & 130.60 & -0.08 & 36012076 & 0.69 \\
4 & 2025 & 293252052 & 1.21 & 130.39 & -0.08 & 36502946 & 0.68 \\
5 & 2027 & 300288874 & 1.19 & 130.18 & -0.08 & 36993817 & 0.67 \\
6 & 2029 & 307325696 & 1.16 & 129.97 & -0.08 & 37484687 & 0.66 \\
7 & 2031 & 314362518 & 1.13 & 129.76 & -0.08 & 37975557 & 0.65 \\
8 & 2033 & 321399339 & 1.11 & 129.55 & -0.08 & 38466427 & 0.64 \\
9 & 2035 & 328436161 & 1.08 & 129.33 & -0.08 & 38957297 & 0.63 \\
10 & 2037 & 335472983 & 1.06 & 129.12 & -0.08 & 39448167 & 0.63 \\
11 & 2039 & 342509805 & 1.04 & 128.91 & -0.08 & 39939037 & 0.62 \\
12 & 2041 & 349546627 & 1.02 & 128.70 & -0.08 & 40429907 & 0.61 \\
13 & 2043 & 356583448 & 1.00 & 128.49 & -0.08 & 40920777 & 0.60 \\
14 & 2045 & 363620270 & 0.98 & 128.28 & -0.08 & 41411648 & 0.60 \\
\multicolumn{2}{c}{ Average } & 317880928 & 1.12 & 129.63 & -0.08 & 38220991 & 0.65 \\
\hline
\end{tabular}

Source: Authors computation 


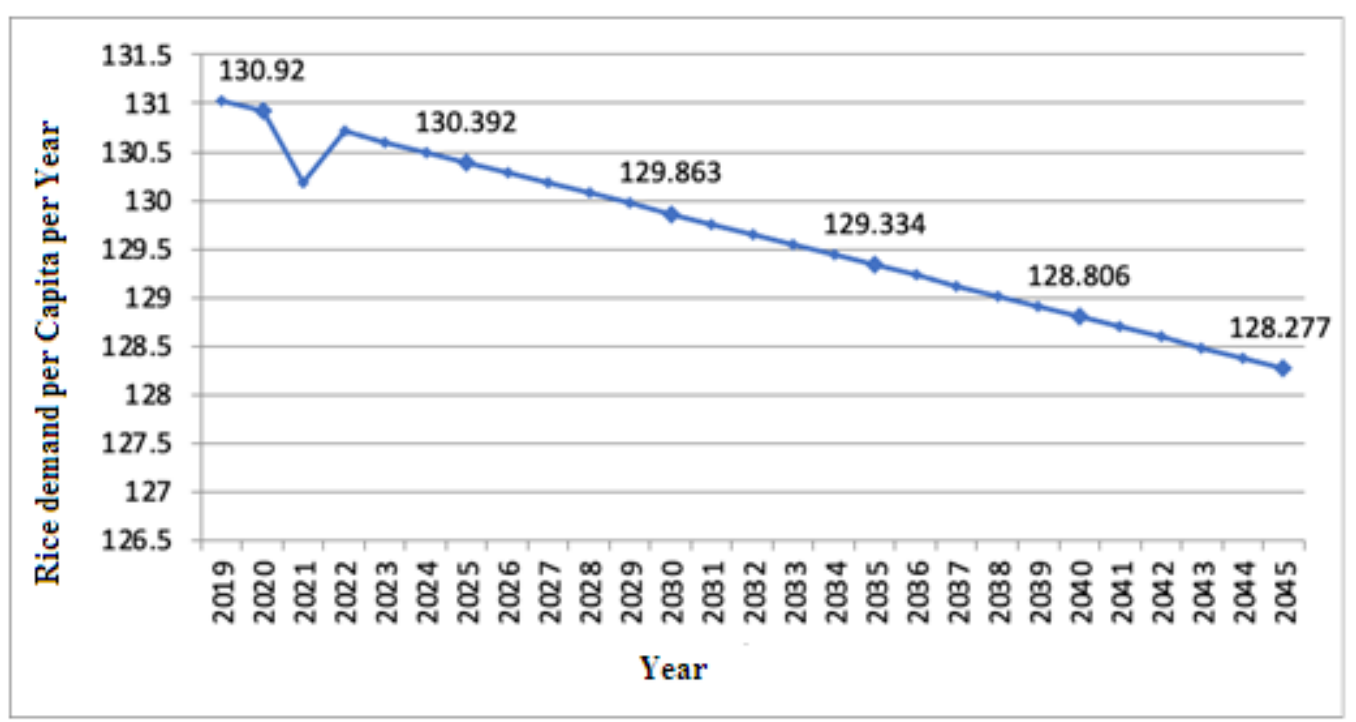

Figure 3. Forecasting of Rice Consumption Per Capita per Year, 2019 - 2045

The forecasting of rice demand in Indonesia in 2025 is 36.5 million tons, in 2035, 39.0 million tons, and in the amount of 2045, are estimated at 41.4 million tons. This difference can occur because the analysis results show that the population growth rate in Indonesia is only able to be reduced to 0.98 percent. In comparison, the expected projection from the BPS data is 0.95 percent. Moreover, this causes a difference in population forecasting in 2045.

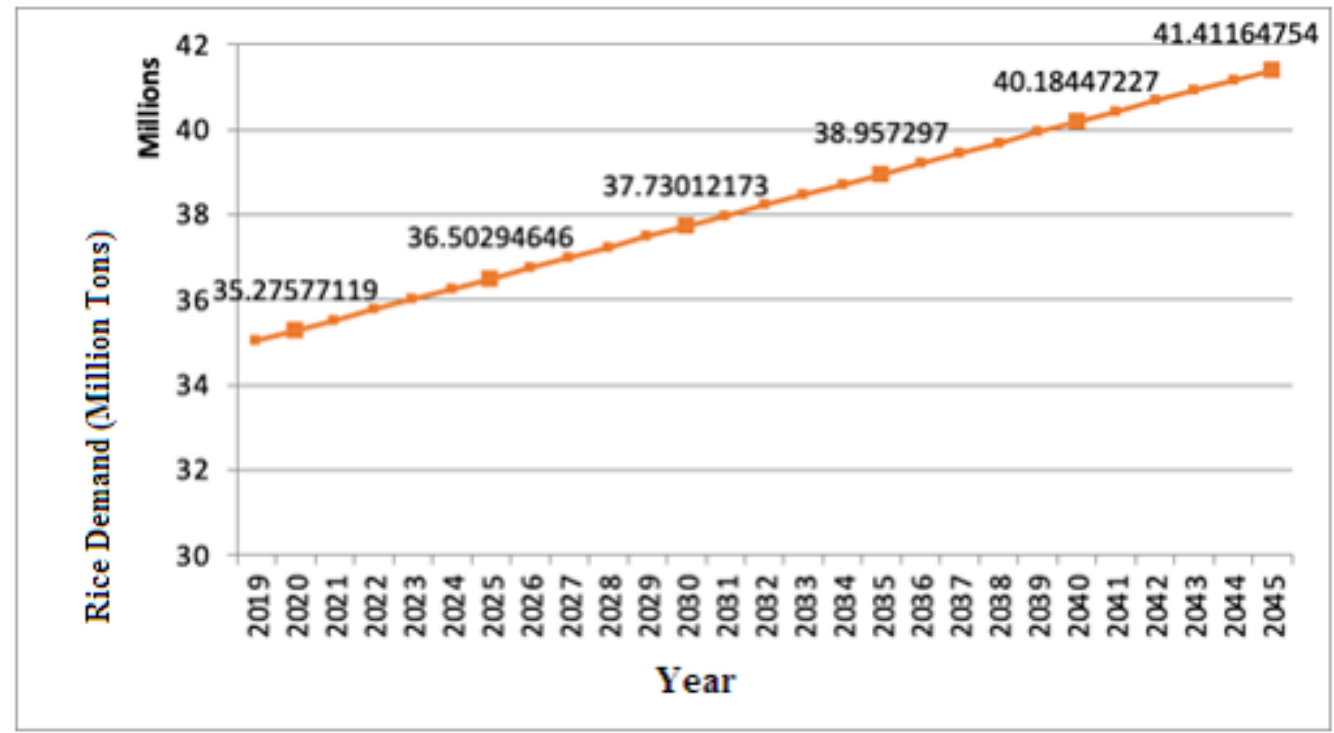

Figure 4. Forecasting of the Indonesian Rice Demand, 2019 - 2045

The total demand for rice above, with rice production in the form of dry rice amounting to 88.60 million tons in 2020, then in 2025 it will need 101.10 million tons, 113.62 million tons in 2030, 126.13 million tons / GKG in 2035, 138.65 million tons in 2040, and 151.15 million tons in 2045. With these projections, Indonesia will be able to meet the domestic consumption needs of rice until 2045.

\section{CONCLUSION}

This study describes Indonesia's rice economic forecasting in 2045, using an ex-ante approach. A total of 12 rice economic models were analyzed using the simultaneous equation model. The result of this study reflects decreasing rice consumption per capita per year. In 2019 rice consumption in Indonesia was 131. $23 \mathrm{~kg}$ per capita per year; In 2025, it is $130.39 \mathrm{~kg}$ per capita per year; in 2035 , it is $129.33 \mathrm{~kg}$ per capita per year. It is estimated that in 2045, rice consumption will be $128.277 \mathrm{~kg}$ per capita per year. The forecasting of rice demand in Indonesia in 2025 is 36.5 million tons, in 2035, 39.0 million tons, and in the amount of 2045 , are estimated at 41.4 million tons. This difference 
can occur because the analysis results show that the population growth rate in Indonesia is only able to be reduced to 0.98 percent. In comparison, the expected projection from the BPS data is 0.95 percent. Moreover, this causes a difference in population forecasting in 2045.

\section{REFERENCES}

Abdulai, A., \& Huffman, W. (2000). Structural adjustment and economic efficiency of rice farmers in northern Ghana. Economic Development and Cultural Change, 48(3), 503-520.

Acee-Eke, B. C. (n.d.). Consumers' Demand for Org Purchase Intentions: Empirical Survey in N.

Agbachom, E. E., Melvin, A., Amata, U., Ettah, O., \& Ubi, G. M. (2019). Strategic Policies in Expanding Frontiers of Food Security among Cassava-based Farmers in Cross River State, Nigeria. Annual Research \& Review in Biology, 1-12.

Arifin, B., Achsani, N. A., Martianto, D., Sari, L. K., \& Firdaus, A. H. (2018). Modeling the Future of Indonesian Food Consumption. Report Submitted to the National Development Planning Agency (Bappenas), World Food Programme (WFP), and Food and Agricultural Organization of the United Nations (FAO). Jakarta. Https://Docs. Wfp. Org/Api/Documents/WFP0000073760/Download.

Biondi, B., Van der Lans, I. A., Mazzocchi, M., Fischer, A. R., Van Trijp, H. C., \& Camanzi, L. (2019). Modelling consumer choice through the random regret minimization model: An application in the food domain. Food Quality and Preference, 73, 97-109.

Choi, K., Chen, J. C., Tan, A. S., Soneji, S., \& Moran, M. B. (2019). Receipt of tobacco direct mail/email discount coupons and trajectories of cigarette smoking behaviours in a nationally representative longitudinal cohort of US adults. Tobacco Control, 28(3), 282-288.

Fadhliani, Z., Luckstead, J., \& Wailes, E. J. (2019). The impacts of multiperil crop insurance on Indonesian rice farmers and production. Agricultural Economics, 50(1), 15-26.

Graham, E. G., Tchale, H., \& Ndione, M. (2020). An Optimal Rice Policy for Sierra Leone: Balancing Consumer and Producer Welfare. The World Bank.

Hidayaturrahman, M., \& Husamah, H. (2020). Participation in building human resources: Independent strategies for facing a demographic expansion in a remote island. Teacher Education and Professional Development In Industry 4.0: Proceedings of the 4th International Conference on Teacher Education and Professional Development
(InCoTEPD 2019), 13-14 November, 2019, Yogyakarta, Indonesia, 141.

Junaidi, J., Yulmardi, Y., \& Hardiani, H. (2020). Food crops-based and horticulture-based villages potential as growth center villages in Jambi Province, Indonesia. Journal of Critical Reviews, 7(9), 514-519.

Maraseni, T. N., Deo, R. C., Qu, J., Gentle, P., \& Neupane, P. R. (2018). An international comparison of rice consumption behaviours and greenhouse gas emissions from rice production. Journal of Cleaner Production, 172, 2288-2300.

Meuwissen, M. P., Feindt, P. H., Spiegel, A., Termeer, C. J., Mathijs, E., de Mey, Y., Finger, R., Balmann, A., Wauters, E., \& Urquhart, J. (2019). A framework to assess the resilience of farming systems. Agricultural Systems, 176, 102656.

Moayedfar, R., Haghshenas, M., Farahmand, S., \& Sharirfi, A. (2020). Assessment of EconomicEnvironmental Consequences of Implementing Policies to Exclude and Reform Fossil Fuel Subsidies in the Mena Region up to the Time Horizon by 2100: Experimental Application of RICE Model.

Mora, O., Le Mouël, C., de Lattre-Gasquet, M., Donnars, C., Dumas, P., Réchauchère, O., Brunelle, T., Manceron, S., Marajo-Petitzon, E., \& Moreau, C. (2020). Exploring the future of land use and food security: A new set of global scenarios. PloS One, 15(7), e0235597.

Movilla-Pateiro, L., Mahou-Lago, X. M., Doval, M. I., \& Simal-Gandara, J. (2020). Toward a sustainable metric and indicators for the goal of sustainability in agricultural and food production. Critical Reviews in Food Science and Nutrition, 1-22.

Neilson, J., Dwiartama, A., Fold, N., \& Permadi, D. (2020). Resource-based industrial policy in an era of global production networks: Strategic coupling in the Indonesian cocoa sector. World Development, 135, 105045.

Nikmatul, K., Ratya, A., Nuhfil, H., \& Wahib, M. A. (2020). The analysis demand for animal source food in Indonesia: Using Quadratic Almost Ideal Demand System. Business: Theory and Practice, 21(1), 427-439.

Pichler, M. (2015). Legal dispossession: State strategies and selectivities in the expansion of Indonesian palm oil and agrofuel production. Development and Change, 46(3), 508-533.

Rusliyadi, M., Jamil, A. B. H. M., Kumalasari, R. T., \& Rouf, A. A. (n.d.). Institutional Role and Asisstance Service Analysis on Food Security Policy Case in Indonesia. In Global Challenges and Strategic Disruptors in Asian Businesses and Economies (pp. 43-59). IGI 
Global.

Sa'diyah, A. A., Anindita, R., Hanani, N., \& Muhaimin, A. W. (2019). The strategic food demand for non poor rural households in Indonesia. EurAsian Journal of BioSciences, 13(2), 2197-2202.

Santilano, A., Godio, A., \& Manzella, A. (2018). Particle swarm optimization for simultaneous analysis of magnetotelluric and time-domain electromagnetic data. Geophysics, 83(3), E151-E159.

Sarwar, M. T., Fountas, G., \& Anastasopoulos, P. C. (2017). Simultaneous estimation of discrete outcome and continuous dependent variable equations: A bivariate random effects modeling approach with unrestricted instruments. Analytic Methods in Accident Research, 16, 23-34.

Setiadi, R., Artiningsih, A., Sophianigrum, M., \& Satriani, T. (2020). The dimension of ruralurban linkage of food security assessment: An Indonesian case study. Asian Geographer, 1-19.
Sulaiman, A. A., Sulaeman, Y., Mustikasari, N., Nursyamsi, D., \& Syakir, A. M. (2019). Increasing sugar production in Indonesia through land suitability analysis and sugar mill restructuring. Land, 8(4), 61.

Utami, N. W. F., Wirawan, I. G. P., Firn, J., Kepakisan, A. N. K., Kusdyana, I. P. G. A., Nicol, S., \& Carwardine, J. (2020). Prioritizing management strategies to achieve multiple outcomes in a globally significant Indonesian protected area. Conservation Science and Practice, e157.

Wicke, B., Sikkema, R., Dornburg, V., \& Faaij, A. (2011). Exploring land use changes and the role of palm oil production in Indonesia and Malaysia. Land Use Policy, 28(1), 193-206. 